\title{
PENYULUHAN TENTANG PEMBERIAN MAKANAN TAMBAHAN UNTUK \\ USIA BALITA 6-24 BULAN (MP ASI) DI POSYANDU RW 08 \\ PUSKESMAS HARAPAN RAYA \\ KOTA PEKANBARU TAHUN 2020
}

\author{
Intan Widya Sari ${ }^{1)}$ Riza Febrianti ${ }^{2}$ \\ STIKes Hang Tuah Pekanbaru \\ Email : intanwidya@htp.ac.id
}

\begin{abstract}
Changes in need from exclusive breastfeeding to complementary foods are generally at the age of 6-24 months, and this period is very sensitive for the incidence of malnutrition in children. Complementary foods do not replace breast milk, but gradually add to the nutritional needs of the baby. The success of offering this MP is also due to the development of the function of the baby's nervous system, digestive tract and kidneys. The purpose of this activity is to increase the knowledge of breastfeeding mothers about complementary foods. The method used in this community service was a question and answer lecture using leaflets. After this counseling, it is hoped that it can increase the knowledge of breastfeeding mothers about complementary foods.
\end{abstract}

Keywords: Supplementary food, breast milk, counseling

\begin{abstract}
ABSTRAK
Perubahan kebutuhan dari ASI eksklusif ke makanan pendamping umumnya terjadi pada usia 6-24 bulan, dan periode ini sangat sensitif untuk terjadinya malnutrisi pada anak. Makanan pendamping tidak menggantikan ASI, tetapi secara bertahap memberi tambahan sesuai kebutuhan gizi bayi. Keberhasilan pemberian MP ini dipengaruhi juga oleh perkembangan fungsi sistem syaraf, saluran cerna dan ginjal bayi. Tujuan pelaksanaan kegiatan ini adalah untuk meningkatkan pengetahuan ibu menyusui tentang MP-ASI. Metode yang digunakandalam pengabdian masyarakat ini adalah ceramah tanya jawab dengan menggunakan leaflet. Setelah penyuluhan ini diharapkan dapat meningkatkan pengetahuan ibu menyusui tentang MP-ASI.
\end{abstract}

Kata Kunci : Makanan Tambahan, ASI, Penyuluhan 
PENDAHULUAN

Makanan pendamping ASI (MP-ASI) harus diberikan sebagai makanan tambahan diberikan apabila ASI tidak mencukupi nutrisi. Perubahan kebutuhan dari ASI eksklusif ke makanan pendamping umumnya terjadi pada usia 6-24 bulan, dan periode ini sangat sensitif untuk terjadinya malnutrisi pada anak. ${ }^{1}$ Pemberian MP-ASI harus dimulai pada usia 6 bulan; nilai gizi MP harus adekuat seperti kandungan dalam ASI, bersih, rasa dan bentuk yang menarik dalam jumlah yang cukup. WHO menyarankan bahwa bayi harus menerima MP pada usia 6 bulan 2-3 kali sehari disamping ASI sampai usia 8 bulan, dan meningkat menjadi 3-4 kali pada usia 9-11 bulan dan pada usia 12-24 bulan tambahan MP 1-2 kali perhari. ${ }^{2}$ Makanan pendamping tidak menggantikan ASI, tetapi secara bertahap memberi tambahan sesuai kebutuhan gizi bayi. Keberhasilan pemberian MP ini dipengaruhi juga oleh perkembangan fungsi sistem syaraf, saluran cerna dan ginjal bayi. ${ }^{3}$

Air susu ibu mengandung enzimenzim yang membantu pencernaan dan juga enzim yang berfungsi sebagai antibakteri seperti lisozim, katalase dan peroksidase. Selain itu ASI mengandung hormon-hormon seperti ACTH, TRH, TSH, EGH, prolaktin, kortikosteroid, prostaglandin dll. Pemberian ASI, mempunyai dampak pada ibu yaitu mengurangi perdarahan postpartum, mempercepat involusi uterus dan menunda kembalinya kesuburan. ${ }^{4,5}$ Pemberian ASI dianjurkan sampai anak berusia 2 tahun yaitu saat anak dapat makan makanan padat dengan baik. Diet ibu mempengaruhi kandungan nutrien dalam ASI. Diet ibu yang mengandung rendah vitamin A dan DHA akan menyebabkan kandungan vitamin A dan DHA dalam ASI rendah.

Tidak semua ibu memproduksi ASI yang cukup, sehingga diperlukan makanan pendamping ataupun makanan pengganti. ${ }^{6}$ Pemerintah telah membuat standar nutrisi susu formula yang boleh masuk ke Indonesia. Pemberian makanan pendamping ini harus disesuaikan dengan maturasi saluran cerna bayi dan kebutuhannya.

MP-ASI merupakan peralihan asupan yang semata berbasis susu menuju ke makanan yang semi padat. Untuk proses ini juga dibutuhkan ketrampilan motorik oral. Ketrampilan motorik oral berkembang dari refleks menghisap menjadi menelan makanan yang berbentuk bukan cairan dengan memindahkan makanan dari lidah bagian depan ke lidah bagian belakang 


\section{METODE PENERAPAN}

Dalam kegiatan pengabdian ini metode yang digunakan adalah dalam bentuk penyuluhan berupa sosialisasi dan metode demonstrasi dengan menggunakan leaflet, lembar bali. Materi yang diberikan dalam penyuluhan ini adalah tentang pemberian makanan tambahan untuk balita usia 6-24 bulan (MP ASI). Pelaksanaan sosialisasi di lakukan sesuai dengan materi makanan tambahan (MP ASI).

\section{HASIL DAN PEMBAHASAN}

\section{A. Hasil Pelaksanaan}

Kegiatan sosialisasi pentingnya penggunaan $\mathrm{KB}$ ini telah di laksanakan pada tanggal 18 Januari 2020 pada 30 orang ibu menyusui yang di berikan penjelasan tentang pedoman pemberian makanan tambahan (MP ASI).

Berdasarkan

pengamatan selama kegiatan berlangsung, kegiatan pegabdian pada masyarakat ini memberikan hasil sebagai berikut :

1. Meningkatnya pengetahuan dan pemahaman ibu menyusui mengenai pentingnya mengetahui pedoman pemberian makanan tambahan pada balilita usia 6-24 bulan (MP ASI) . Hal ini dilihat dari kemampuan dan semangat ibu-ibu dalam menjawab pertanyaan yang diajukan oleh pemateri.

2. Meningkatnya rasa mencoba ibuibu dalam membuat makanan tambahan dengan berbagai variasi menu setelah dilaksanakannya sosialisasi ini.
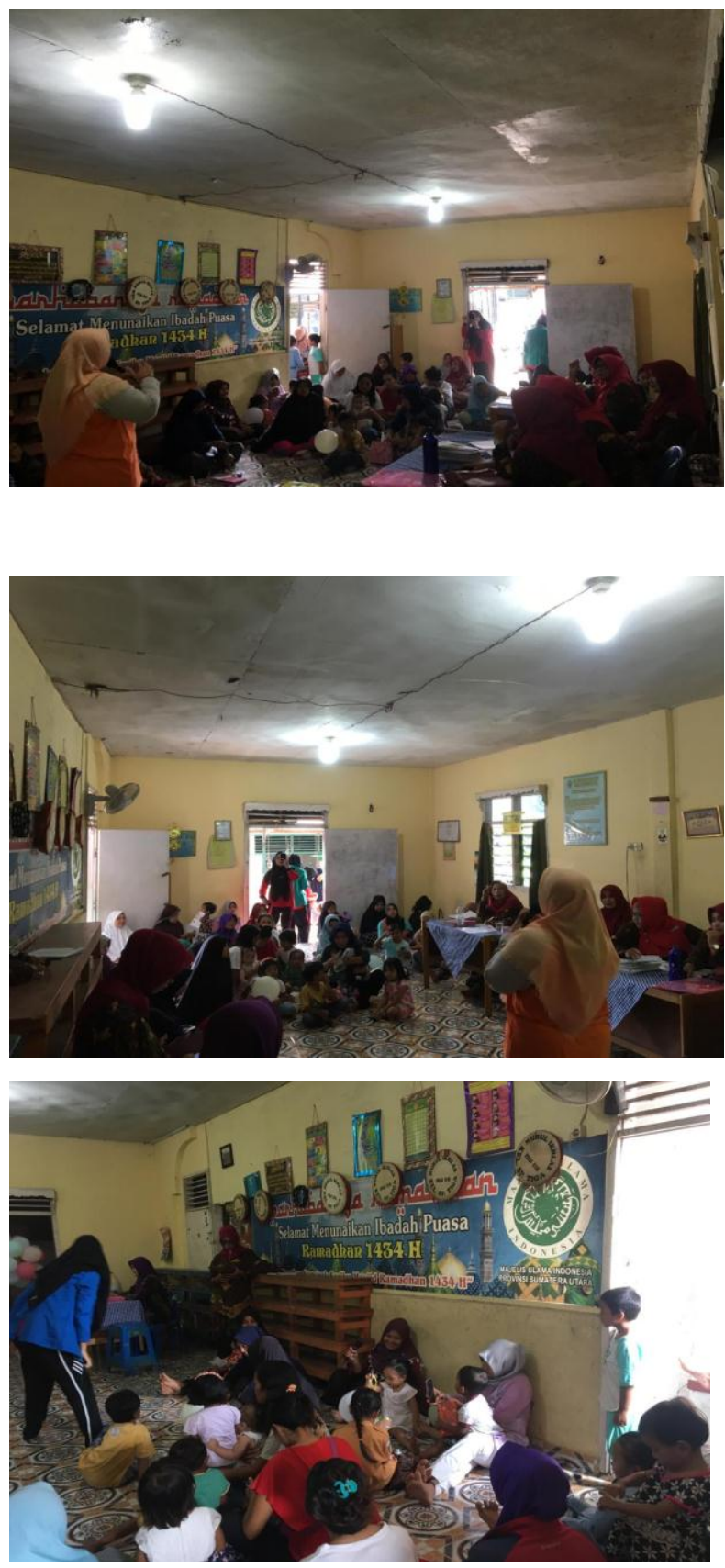


\section{B. Pembahasan}

MP-ASI adalah makanan atau minuman selain ASI yang mengandung nutrien yang diberikan kepada bayi selama periode pemberian makanan peralihan (complementery feeding) yaitu pada saat makanan/minuman lain diberikan bersama pemberian ASI. ${ }^{1}$

MP-ASI adalah makanan atau minuman yang mengandung zat gizi, diberikan kepada bayi atau anak usia 6-24 bulan guna memenuhi kebutuhan gizi selain dari ASI. ${ }^{8} \mathrm{MP}-$ ASI merupakan makanan peralihan dari ASI ke makanan keluarga. Pengenalan dan pemberian MP-ASI harus dilakukan secara bertahap baik bentuk maupun jumlah. Hal ini dimaksudkan untuk menyesuaikan kemampuan alat pencernaan bayi dalam menerima MP-ASI.

\section{KESIMPULAN}

Dapat disimpulkan bahwa:

1. Mayoritas penduduk belum sepenuhnya mengetahui tentang pedoman pemberian makanan tambahan (MP ASI)

2. Sosialisasi ini meningkatkan pengetahuan ibu tentang pentignya pedoman pemberian makanan tambahan (MP ASI) pada balita usia (6-24 bulan)

\section{DAFTAR PUSTAKA}

World Health Organization, Complimentary feeding: Report of the Global Consultation and of Guiding Principles for Complimentary Feeding of the Breastfed Child Geneva, , 2001.

Departemen Kesehatan RI. Pedoman Umum Pemberian Makanan Pendamping Air Susu Ibu (MP-ASI Lokal). 2006.

Departemen Kesehatan RI. Peranan Dokter Dalam Peningkatan Penggunaan ASI. 2004.

Dewey KG, Cohen RJ, Brown KH, Rivera LL. Age of Introduction of Complementary Foods and Growth of Term, Low Birth Weight, Breastfed Infants: A Randomized Intervention Study in Honduras. Am J Clin Nutr 1999; 69:678-86.

Greiner T. Sustained Breastfeeding, Complementation and Care Food and Nutrition Bull 1995; 16:313-9.

Nasar, SS. Indonesia Menyusui. IDAI 2010:267-279. 